\title{
Synthesis of cyclodextrin derivatives with monosacharides and their binding with ampicillin and selected lectins
}

\author{
Maria Lampropoulou, ${ }^{\text {a }}$ Konstantinos Misiakos, ${ }^{\text {a }}$ Maria Paravatou, ${ }^{\mathrm{b}}$ Irene M. Mavridis, ${ }^{\mathrm{a}}$ \\ and Konstantina Yannakopoulou ${ }^{\mathrm{a} *}$ \\ ${ }^{a}$ Institute of Nanoscience and Nanotechnology \\ ${ }^{b}$ Institute of Nuclear \& Radiological Sciences \& Technology, Energy \& Safety, \\ National Centre for Scientific Research “Demokritos”, Aghia Paraskevi, 15310, Athens, Greece \\ E-mail: k.yannakopoulou@inn.demokritos.gr
}

Dedicated to Professor Michael Orfanopoulos on the occasion of his $67^{\text {th }}$ birthday

DOI: http://dx.doi.org/10.3998/ark.5550190.p009.003

\begin{abstract}
$\beta$ - and $\gamma$-Cyclodextrins connected on their narrow side via 6 bond-linkers with monosaccharides (Man, GlcNAc) suitable for bacterial lectin recognition, along with reference mono-analogues were prepared. The resulting compounds: (a) posses a functional cavity forming inclusion complexes with a model guest molecule and with the antibiotic ampicillin; (b) inhibit by more than $30 \%$ the hydrolysis of ampicillin in the presence of the enzyme $\beta$-lactamase; (c) interact stronger with surface immobilized lectins than the reference mono-analogues. The present work suggests that combining the lectin recognition property of the compounds with their ability to encapsulate antibiotics could be used to target and kill bacteria.
\end{abstract}

Keywords: Cyclodextrin, glycoclusters, monosaccharides, bacteria, antibiotics, ampicillin

\section{Introduction}

Pathogenic bacteria frequently colonize and infect host tissues by adhesion of lectins present on their surface to complementary carbohydrates of the host cells. ${ }^{1,2}$ Among hundreds of monosaccharides found in nature lectins recognize just a few, primarily D-glucose (Glc), Dgalactose (Gal), D-mannose (Man), D- $N$-acetylglucosamine (GlcNAc), D- $N$-acetylgalactosamine (GalNAc), L-fucose (Fuc) and D- $N$-acetylneuraminic acid. ${ }^{3}$ Therefore, a monosaccharide can be a targeting moiety recognized by a bacterial lectin. However, since the binding affinities of monovalent carbohydrates to lectins are weak to moderate ${ }^{1}$ nature utilizes multivalency to create cooperative mechanisms to increase lectin-carbohydrate affinities. The multivalency of ligands ${ }^{4,5}$ 
as well as the multiple carbohydrate binding modules on the lectins provide strengthened binding with amplified specificity of the recognition. ${ }^{1}$

Cyclodextrins (CDs) offer unique features towards the formation of glycoclusters for biological applications, since they are biocompatible and can be easily modified in their primary side with carbohydrate moieties. Per-carbohydrate modified CD derivatives have been reported ${ }^{6-}$ 15 demonstrating the advantages of multivalency and clustering effect in homo- and heterogeneously decorated cyclodextrin scaffolds. Herein, the synthesis of a series of new cyclodextrin-based glycoclusters with seven and eight monosaccharide units connected to the CD core via optimally sized linkers, as well as the corresponding monosubstituted derivatives, is reported. The compounds also form complexes with a common $\beta$-lactam antibiotic, ampicillin, and partially inhibit its hydrolysis rate in the presence of a $\beta$-lactamase enzyme, in buffer conditions and at the same time they bind strongly with specific lectins, which is exactly the objective of the present work: to show the potential of the synthesized compounds to act as stabilizing agents for antibiotics which can be carried to the bacterial surface.

\section{Results and Discussion}

HATU-mediated amide bond formation between 2'-aminoethyl-appended monosaccharides and the per-carboxyethylthio-terminated cyclodextrin derivatives $\mathbf{1}$ and $\mathbf{2}^{16}$ and the novel monocarboxy-derivative 7 (Scheme 1) gave the monodisperse products 3-6 and 8-9, respectively, whereas using HOBT/DCC coupling under numerous conditions (ratio, temperature, duration) products of inferior quality were obtained.

The monosaccharides with 2'-aminoethyl linkers were synthesized according to literature methods from the parent monosaccharides: 2 -aminoethyl- $\alpha$-D-mannopyranose was prepared in five steps and $59 \%$ overall yield ${ }^{17}$ and 2 -aminoethyl-2-acetamide-2-deoxy- $\alpha$-D-glucopyranose was prepared in three steps and 69\% overall yield from the known azido precursor. ${ }^{18,19}$ The linker chain between the amino-end and the monosaccharides was limited to two carbon atoms so that after connection to the $\mathrm{CD}$ core the total carbon atoms would be 6 . Literature suggests ${ }^{14}$ that CD-based glycoclusters with connectors 2-5 carbon atoms apart from the core have much higher affinity towards blood glycoproteins, compared with glycoclusters having longer linkers. In all compounds (Scheme 1), connection of the monosaccharide part with the CD core was verified by detecting either the $\mathrm{N} \underline{H}---\underline{C}=\mathrm{O}$ scalar coupling through bonds (2D HMBC NMR spectra) or the dipolar through space coupling (ROESY/NOESY NMR spectra) between the two components. In addition, two derivatives with only one monosaccharide unit on the CD were synthesised from the mono-carboxyl precursor $\mathbf{7}$ and characterised in a similar manner.

Guest binding and partial inhibition of enzymatic degradation of ampicillin by $\boldsymbol{\beta}$-lactamase. Although per-substitution of the primary hydroxyl groups of a cyclodextrin with carbohydrate moieties is expected to produce glycoclusters that bind stronger to lectins than the 
mono-analogs ${ }^{14}$ the cavity inclusion ability may be decreased or increased, compared with the unsubstituted CDs, while hyperbranched derivatives may totally loose their cavity binding capacity. ${ }^{14,20}$ Therefore, the inclusion ability of the cavity of the current glycoclusters was initially tested with a typical guest molecule, p-tert-butylbenzoic acid, which is known to form strong inclusion complexes with $\beta$-CD in solution ${ }^{21}\left(K_{\text {assoc }} \geq 10^{4} \mathrm{M}^{-1}\right)$ and in the crystalline state. ${ }^{22}$ In addition, this guest molecule lacks NMR signals in the carbohydrate region (5-2.5 ppm). 2D ROESY NMR spectra revealed clear dipolar interactions between the AA'XX' aromatic proton doublets of the guest at 7.75 and $7.45 \mathrm{ppm}$ and the signals attributed to the cyclodextrin cavity protons of $\mathbf{4}$ at $\sim 3.9 \mathrm{ppm}$. Therefore the cavity is indeed capable of hosting a model molecule while the linkers with the monosaccharide appendages seem to neither block the cavity nor interfere with the guest inclusion.

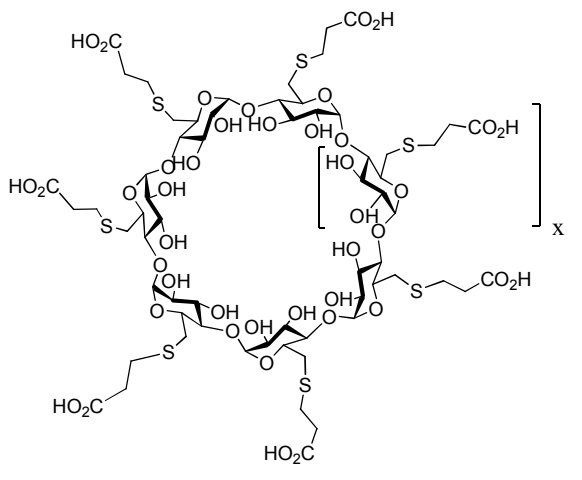

1: $x=1$

2: $x=2$

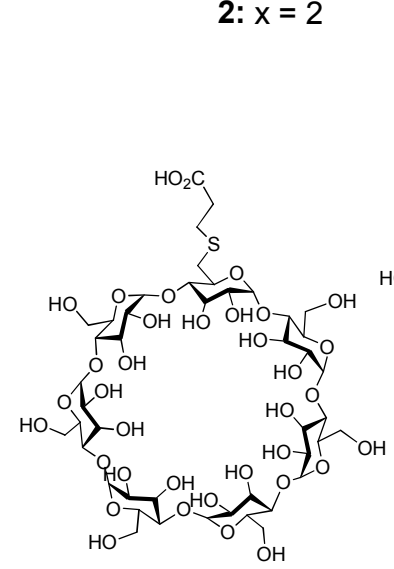

7
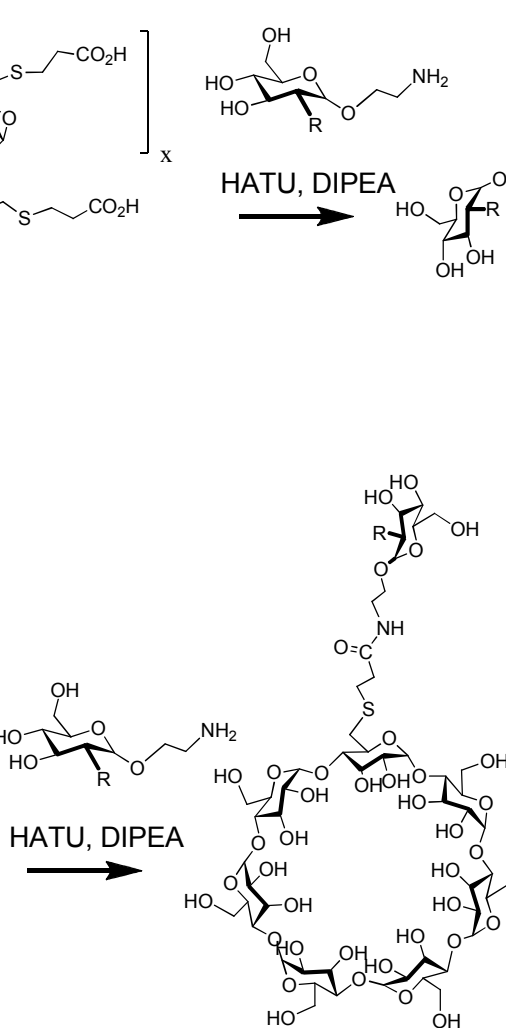

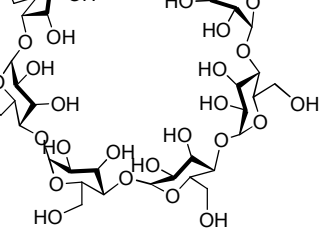

8: $\alpha$-D-Man

9: $\alpha$-D-GICNAC

Scheme 1. Preparation of glycoclusters and monosaccharide-CD derivatives. 
Ampicillin, a very frequently used broad spectrum $\beta$-lactam antibiotic, was tested next. We have previously shown by NMR spectroscopy and mass spectrometry ${ }^{23}$ that ampicillin complexes with 2 via both cavity inclusion and external interactions, ${ }^{23,24}$ thus demonstrating the contribution and importance of non-cavity effects. ${ }^{24}$ Ampicillin solutions in the presence of $\mathbf{4}$ and $\mathbf{6}$ were examined presently by 2D ROESY NMR experiments. The spectra showed clear intermolecular interactions of the drug's phenyl group with the cavity protons of $\mathbf{4}$ and $\mathbf{6}$ indicating that the drug is encapsulated in the cavity of the compounds.

The rate of enzymatic hydrolysis of ampicillin in the presence of $\beta$-lactamase (EC 3.5.2.6) from Enterobacter cloacae was studied in buffered aqueous solutions (phosphate, $\mathrm{pH} 7$ ) of $\mathbf{2 , 4}$ and 6 and of the linear analogue of $\beta$-CD, maltoheptaose, at constant temperature $\left(25^{\circ} \mathrm{C}\right)$. Pseudo first-order conditions were used, i.e., 5- to 10-fold excess of host compounds and maltoheptaose. Degradation was quantified by monitoring the area decrease corresponding to the signals of the two methyl groups of ampicillin by ${ }^{1} \mathrm{H}$ NMR spectroscopy; therefore the rate of degradation was defined as the ratio of the integral of the methyl peaks over the total integral of the phenyl peaks, $v s$ time. The error of the method was assessed as $\pm 10 \%$ by running the hydrolysis experiments of ampicillin alone in triplicate. The degradation profiles were fitted satisfactorily into a mono-exponential decay equation and consequently linear plots of $\ln \left(\left[\mathrm{A}_{0}\right] /[\mathrm{A}]\right)$ vs time were obtained (where $\left[\mathrm{A}_{0}\right]$ and $[\mathrm{A}]$ are the ampicillin concentrations initially and at time $\mathrm{t}$ ). The rates thus calculated (Table 1) show that 2 inhibits the degradation of ampicillin by $\sim 50 \%$, as shown previously by this group, ${ }^{23}$ while $\mathbf{4}$ and $\mathbf{6}$ inhibit hydrolysis by $\sim 30$ and $\sim 40 \%$, respectively, statistically different from linear maltoheptaose $(\sim 20 \%)$. The derivatives thus offer protection to ampicillin presumably via cavity inclusion. However, external interactions (non-cavity) effects, as shown before ${ }^{23}$ cannot be ruled out. The combined effects result in partial inhibition of the ampicillin degradation rates which are, in descending order, $2>\mathbf{6} \geq \mathbf{4}>$ maltoheptaose. The results show that the prepared glycoclusters can bind and partially protect ampicillin from degradation.

Table 1. Rates of hydrolysis of ampicillin in the presence of $\beta$-lactamase $\left(25^{\circ} \mathrm{C}\right)$

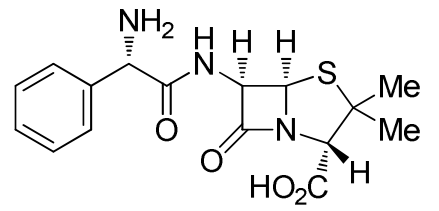

\begin{tabular}{ccc}
\hline $\begin{array}{c}k \\
\left(\times 10^{-4} \mathrm{~h}^{-1}\right)\end{array}$ & Enzymatic Hydrolysis of & $\mathrm{R}^{2}$ \\
\hline $108( \pm 4.0)$ & ampicillin & 0.996 \\
$44.2( \pm 2.6)$ & ampicillin/2 & 0.988 \\
$74.7( \pm 2.5)$ & ampicillin/4 & 0.995 \\
$63.3( \pm 4.3)$ & ampicillin/6 & 0.986 \\
$90.3( \pm 1.6)$ & ampicillin/maltoheptaose & 0.999 \\
\hline
\end{tabular}


Interaction of glycoclusters with selected lectins: real-time monitoring of binding by White Light Reflectance Spectroscopy. Two selected commercial lectins were tested in vitro: (a) wheat germ agglutinin (WGA) that shows binding affinity for GlcNAc, has four sugar binding pockets per monomer and in the crystal forms tetramers, ${ }^{25}$ (b) galanthus nivalis (GNL), ${ }^{26}$ a mannose-binding lectin that possesses three sugar binding pockets per monomer. White Light Reflectance Spectroscopy (WLRS) was used, as was described previously, ${ }^{27,28}$ to monitor and quantify GNL interaction with $\mathbf{3}$ and WGA interaction with $\mathbf{5}$. The lectins were deposited on a surface in a fluidic cell (see Experimental) and formed a stable layer upon which solutions of $\mathbf{3}$ (or 5) were introduced. The binding events were detected in real time as red shifts of the resonant wavelength, $\lambda_{\max }$, where resonance is meant as a local extremum in the reflectance spectrum. An initial $\Delta \lambda_{\max }$ increase was followed by a plateau signifying the end of the binding event; subsequent washing resulted in a drop of the $\Delta \lambda_{\max }$ change (off process). From the experimental data $\left(\Delta \lambda_{\max } v s\right.$ time) and the slopes of the on and off curves which are proportional to the on and off binding reaction rates $\left(k_{\mathrm{on}}, k_{\mathrm{off}}\right.$, respectively, see Supplementary Material) combined with the compound solution concentrations the binding as well as dissociation rate constants and the corresponding equilibrium constants, $K=k_{\text {on }} / k_{\text {off }}\left(\mathrm{M}^{-1}\right)$ were determined (Table 2).

Table 2. Binding, $k_{o n}$, dissociation, $k_{o f f}$, rate constants and equilibrium constants, $K$, obtained from the WLRS curves

\begin{tabular}{ccccccc}
\hline & \multicolumn{3}{c}{ ASSOCIATION } & \multicolumn{3}{c}{ DISSOCIATION } \\
\hline Comp. & Conc. (M) & $\mathrm{R}^{2}$ & $k_{\text {on }}\left(\mathrm{M}^{-1} \mathrm{~s}^{-1}\right)$ & $k_{\text {off }}\left(\mathrm{s}^{-1}\right)$ & $\mathrm{R}^{2}$ & $K=k_{\text {on }} / k_{\text {off }}\left(\mathrm{M}^{-1}\right)$ \\
\hline \multicolumn{7}{c}{$\mathbf{G N L}$} \\
$\mathbf{3}$ & $10^{-4}$ & 0.986 & 10 & $3.3 \times 10^{-6}$ & 0.902 & $3.0 \times 10^{6}$ \\
& \multicolumn{5}{c}{ WGA } \\
$\mathbf{5}$ & $10^{-5}$ & 0.973 & 49 & $1.0 \times 10^{-3}$ & 0.933 & $4.9 \times 10^{4}$ \\
\hline
\end{tabular}

The binding to the corresponding underlying lectin layer was strong for both $\mathbf{3}$ and $\mathbf{5}$ whereas no binding was observed for the mono-substituted derivatives (e.g., solution of $\mathbf{8}$ applied onto WGA layer) or the monosaccharide alone. The binding constant for 5 with WGA as determined falls within the range of association constants $\left(0.6 \times 10^{4}\right.$ to $\left.6.6 \times 10^{4} \mathrm{M}^{-1}\right)$ determined by SPR measurements of surface immobilized WGA with di- and trivalent GlcNAc glycosides. ${ }^{29}$ A high association constant was determined between 3 and GNL that forms three binding pockets per lectin molecule, although the goodness of fit is not perfect. Fitting of the binding curves to a biexponential equation with two time constants was successful as well $\left(\mathrm{R}^{2}>0.990\right)$, indicating that the binding between the above lectins and $\mathbf{3}$ or $\mathbf{5}$ is not a straightforward process, thus the data in Table 2 represent trends and orders of magnitude rather than strict values. However, these experiments indicate that under the conditions described the lectins were immobilized with retention of their functionality and displayed strong binding with the compounds bearing 
multiple copies of complementary recognition monosaccharides (multivalency effect) but not with the singly substituted compounds.

The synthesized compounds are capable for binding with the antibiotic ampicillin, the enzymatic hydrolysis of which they inhibit by up to $30 \%$ while they are also recognized and bound by complementary lectins. Thus they may be useful in targeting bacteria expressing complementary lectins and in combining this property with inclusion and transfer of antibiotics.

\section{Experimental Section}

General. Deuterium oxide $\left(\mathrm{D}_{2} \mathrm{O}\right)$, deuterated dimethylsulfoxide (DMSO- $\left.d_{6}\right)$ and deuterated chloroform $\left(\mathrm{CDCl}_{3}\right)$ were purchased from Deutero $\mathrm{GmbH}$. Deuterated methanol $\left(\mathrm{CD}_{3} \mathrm{OD}\right)$ was a product of Merck. $\beta$-CD was a product of CycloLab. $\beta$-CD and derivatives were dried by heating at $70{ }^{\circ} \mathrm{C}$ under vacuum for $20 \mathrm{~h}$ before reaction. 1,2-Diaminoethane was distilled from a mixture of $\mathrm{CaO}-\mathrm{KOH}$ and stored over $4 \AA$ molecular sieves. The dialysis membranes (cellulose tubing, benzoylated, $\left.\mathrm{MW}_{\mathrm{CO}} 2 \mathrm{kD}\right), \alpha, \beta$-D-(+)-mannose and $N$-acetyl-D-(+)-glucosamine, $O$-(7-azabenzotriazol-1-yl)- $N, N, N^{\prime}, N^{\prime}$-tetramethyluronium hexafluorophosphate (HATU) and dry DMF were purchased from Sigma-Aldrich. Flash column chromatography silica gel 60 (Mesh 0.040$0.063 \mathrm{~mm}$ ) was purchased from Merck. $N, N$-diisopropylethylamine (DIPEA) was used as received. The known compounds (1, 2 and 2'-aminoethyl-monosaccharides), were prepared according to literature methods, as indicated in the introduction. $\beta$-Lactamase (EC 3.5.2.6) from Enterobactercloacae $\geq 97 \%$ pure powder was obtained from Sigma-Aldrich. Lectins WGA (wheat germ agglutinin from Triticum vulgaris, lyophylized powder, $<20 \mu \mathrm{g} / \mathrm{mL}$ agglutination activity) and GNL (galanthus nivalis, lyophylized powder, $<20 \mu \mathrm{g} / \mathrm{mL}$ agglutination activity) were purchased from Sigma. 1D and 2D NMR spectra were run on a Bruker Avance $500 \mathrm{MHz}$ spectrometer. MALDI-TOF MS spectra were obtained using Autoflex (Bruker Daltonics) at the "G. Ronzoni Institute, Milan, Italy; the samples were solutions in $\mathrm{H}_{2} \mathrm{O}(\sim 3 \mathrm{mg} / \mathrm{mL})$; matrix solution: $10 \mathrm{mg} / \mathrm{mL}$ of 2,5-dihydroxybenzoic acid (DHB) in EtOH 80\%; $1 \mu \mathrm{L}$ of the sample solution was added to $5 \mu \mathrm{L}$ of the matrix solution and then $1 \mu \mathrm{L}$ of the mixture was spotted on the target and left to air-dry. The spectra were recorded both in Linear and Reflectron modes, in positive polarity, both calibrated in the expected mass ranges. Elemental analyses were performed in house on a Perkin Elmer 2400 instrument. Melting points were determined on an Electrothermal IA9100 digital apparatus $\left(25-400{ }^{\circ} \mathrm{C}\right.$ range $)$.

Mono[6-(carboxyethylthio)-6-deoxy]- $\beta$-cyclodextrin (7). To a solution of 3-mercaptopropanoic acid $(14.6 \mu \mathrm{L}, 0.168 \mathrm{mmol})$ in DMF $(2 \mathrm{~mL})$ sodium hydride $(15 \mathrm{mg}, 0.620 \mathrm{mmol})$ was added in 10 equal portions and the mixture was stirred for $1 \mathrm{~h}$. Then 6-mono- $p$-toluenesulfonyl$\beta$-cyclodextrin ${ }^{30}(100 \mathrm{mg}, 0.077 \mathrm{mmol})$ was added and the whole was stirred at $100{ }^{\circ} \mathrm{C}$ for $2 \mathrm{~h}$. The mixture was allowed to cool to room temperature and then water was added $(2 \mathrm{~mL})$. The solvent was driven off under vacuum, the compound was dissolved in minimum volume of 
water, the $\mathrm{pH}$ was adjusted to 7 and the solution was dialysed for 1 day. The desired product was obtained after drying as a colorless solid (94 mg, 98\% yield). $\mathrm{Mp}>222{ }^{\circ} \mathrm{C}$ (decomp.); ${ }^{1} \mathrm{H}$ NMR $\left(\mathrm{D}_{2} \mathrm{O}, 298 \mathrm{~K}, 500 \mathrm{MHz}\right) \delta_{\mathrm{H}} 5.15$ (brs, 1H, H1'), 5.09 (brs, 6H, H1), 3.96-3.88 (m, 22H), 3.69$3.59(\mathrm{~m}, 12 \mathrm{H}), 3.17(\mathrm{~m}, 1 \mathrm{H}), 2.94-2.85(\mathrm{~m}, 2 \mathrm{H}), 2.63(\mathrm{~m}, 2 \mathrm{H}) \mathrm{ppm} .{ }^{13} \mathrm{C} \mathrm{NMR}\left(\mathrm{D}_{2} \mathrm{O}, 125 \mathrm{MHz}\right)$ $\delta_{\mathrm{C}} 180.8(\mathrm{C}=\mathrm{O}), 102.0(\mathrm{C} 1), 101.8\left(\mathrm{C} 1\right.$ '), $81.3(\mathrm{C} 4), 73.3(\mathrm{C} 3), 72.3(\mathrm{C} 2), 72.1(\mathrm{C} 5), 60.4\left(\mathrm{C}^{\prime}\right)$, 37.8 (C7), 33.2 (C6), 29.4 (C8) ppm. MS (MALDI-TOF) m/z: 1245.67 ([M+Na] $]^{+}$, calcd.: 1245.37).

\section{Coupling reactions}

Octakis-\{6-deoxy-6-S-[6-( $\alpha$-D-mannopyranose-1'-yl)-4-aza-3-oxohex-1-yl]-6-thio\}- $\gamma$-cyclodextrin (4). HATU (266 mg, $0.701 \mathrm{mmol}$ ) was added to a stirred solution of octakis[6(oxycarbonylethylthio)-6-deoxy]- $\gamma$-cyclodextrin 2 (50 mg, $0.023 \mathrm{mmol})$ in DMF $(16 \mathrm{~mL})$ at $0{ }^{\circ} \mathrm{C}$. After $1 \mathrm{~h}$ at ambient temperature DIPEA (85 $\mu \mathrm{L}, 0.499 \mathrm{mmol})$ and 2'-aminoethyl- $\alpha$-Dmannopyranose $(69 \mathrm{mg}, 0.312 \mathrm{mmol}$ ) were added and the mixture was left to stir for $48 \mathrm{~h}$. The solvent was then evaporated to dryness, the resulting solid was dissolved in doubly distilled water $(3 \mathrm{~mL})$ the $\mathrm{pH}$ was adjusted to 7 with $1 \mathrm{~N} \mathrm{HCl}$ and the solution was dialysed for $48 \mathrm{~h}$ to remove the low-molecular-weight impurities. Lyophilization afforded an off-white solid (84 $\mathrm{mg}$, 74\%). Mp >188 ${ }^{\circ} \mathrm{C}$ (decomp.); ${ }^{1} \mathrm{H}$ NMR $\left(\mathrm{D}_{2} \mathrm{O}, 298 \mathrm{~K}, 500 \mathrm{MHz}\right) \delta_{\mathrm{H}} 5.15$ (brs, $\left.1 \mathrm{H}, \mathrm{CD}-\mathrm{H} 1\right), 4.88$ (s, 1H, Man-H1), 3.96 (s, 1H, Man-H2), 3.91-3.86 (m, 3H, CD-H3, Man-H4, Man-H6), 3.80 (brs, 3H, Man-H3, Man-H7, Man-H6'), 3.70 (s, 1H, CD-H5), 3.68 (s, 1H, Man-H5), 3.66 (s, 1H, CD-H2), 3.63 (brs, 2H, Man-H7', CD-H4), 3.49-3.43 (m, 2H, Man-H8), 3.28-3.26 (m, 1H, CDH6), 2.96 (s, 3H, CD-H6', CD-H8), 2.62 (s, CD-H7) ppm. ${ }^{13} \mathrm{C}$ NMR (D $\left.{ }_{2} \mathrm{O}, 125 \mathrm{MHz}\right) \delta_{C} 173.6$ $(\mathrm{C}=\mathrm{O}$ ), 101.4 (CD C1), 99.4 (Man-C1), 83.7 (CD-C4), 72.4 (Man-C4, CD-C2), 71.8 (CD-C3, C5), 70.3 (Man-C3), 69.8 (Man-C2), 66.3 (Man-C5), 65.6 (Man-C7), 60.5 (Man-C6), 38.7 (ManC8), 35.6 (CD-C7), 32.8 (CD-C6), 28.3 (CD-C8) ppm. MS (MALDI-TOF) m/z: 3664.24 $\left([\mathrm{M}+\mathrm{Na}]^{+}\right)$, calcd. for $\mathrm{C}_{136} \mathrm{H}_{232} \mathrm{O}_{88} \mathrm{~S}_{8} \mathrm{~N}_{8} \mathrm{Na}$ : 3664.17. Elemental analysis calcd. for $\mathrm{C}_{136} \mathrm{H}_{232} \mathrm{~N}_{8} \mathrm{O}_{88} \mathrm{~S}_{8} \cdot 12 \mathrm{H}_{2} \mathrm{O}(\%)$ : C 42.32, H 6.68, N 2.90; found C 42.12, H 6.62, N 2.84.

\section{Heptakis $\{6-d e o x y-6-S$-[6-( $\alpha$-D-mannopyranose-1'-yl)-4-aza-3-oxohex-1-yl]-6-thio\}- $\beta$ -}

cyclodextrin (3). The title compound was obtained using heptakis[6-(oxycarbonylethylthio)-6deoxy]- $\beta$-cyclodextrin (1) $(85 \mathrm{mg}, 0.045 \mathrm{mmol}$ ) and 2'-aminoethyl- $\alpha$-D-mannopyranose (118 $\mathrm{mg}, 0.529 \mathrm{mmol})$. The same ratio of equivalents of reagents as for 4 were used: HATU (454 mg, $1.195 \mathrm{mmol})$, DMF (13 mL), DIPEA (143 $\mu \mathrm{L}, 0.541 \mathrm{mmol})$. Off-white solid, (142 $\mathrm{mg}, 81 \%)$. $\mathrm{Mp}>158{ }^{\circ} \mathrm{C}$ (decomp.); ${ }^{1} \mathrm{H}$ NMR $\left(\mathrm{D}_{2} \mathrm{O}, 298 \mathrm{~K}, 500 \mathrm{MHz}\right) \delta_{\mathrm{H}} 5.13$ (brs, $1 \mathrm{H}, \mathrm{CD}-\mathrm{H} 1$ ), 4.88 (s, 1H, Man-H1), 3.96 (s, 2H, Man-H2, CD-H3), 3.89 (brs, 1H, Man-H4), 3.87 (brs, 1H, Man-H6), 3.80 (brs, 3H, Man-H3, Man-H7, Man-H6'), 3.49-3.42 (m, 4H, Man-H5), 3.25-3.20 (m, 1H, CDH6), 2.95 (brs, 3H, CD-H8, CD-H6'), 2.60 (s, 2H, CD-H7) ppm. ${ }^{13} \mathrm{C}$ NMR $\left(\mathrm{D}_{2} \mathrm{O}, 125 \mathrm{MHz}\right) \delta_{\mathrm{C}}$ 173.6 (C=O), 101.4 (CD-C1), 99.4 (Man-C1), 83.9 (CD-C4), 72.5 (Man-C4, CD-C2), 71.5 (CDC3, CD-C5), 70.2 (Man-C3), 69.7 (Man-C2), 66.3 (Man-C5), 65.5 (Man-C7), 60.5 (Man-C6), 38.6 (Man-C8), 35.6 (CD-C7), 32.8 (CD-C6), 28.4 (CD-C8) ppm. MS (MALDI-TOF) m/z: 
$3209.15\left([M+\mathrm{Na}]^{+}\right)$, calcd for $\mathrm{C}_{119} \mathrm{H}_{203} \mathrm{O}_{77} \mathrm{~S}_{7} \mathrm{~N}_{7} \mathrm{Na}$ : 3209.02. Elemental analysis calcd. for $\mathrm{C}_{119} \mathrm{H}_{203} \mathrm{~N}_{7} \mathrm{O}_{77} \mathrm{~S}_{7} \cdot 9 \mathrm{H}_{2} \mathrm{O}(\%)$ : C 42.66, H 6.65, N 2.93; found C 42.19, H 6.56, N 3.30.

Heptakis\{6-deoxy-6-S-[6-(2-acetamide-2-deoxy- $\alpha$-D-glucopyranose-1'-yl)-4-aza-3-oxohex-1yl]-6-thio\}- $\boldsymbol{\beta}$-cyclodextrin (5). The title compound was obtained using $\mathbf{1}$ (100 $\mathrm{mg}, 0.052 \mathrm{mmol})$ and 2'-aminoethyl-2-acetamide-2-deoxy- $\alpha$-D-glucopyranose (165 mg, $0.624 \mathrm{mmol})$. The same ratio of equivalents of reagents as described above for 4 were used: HATU (535 mg, 1.407 mmol), DMF (23 mL), DIPEA (168 $\mu \mathrm{L}, 0.991 \mathrm{mmol})$. Colorless solid (182 mg, 83\%). Mp >180 ${ }^{\circ} \mathrm{C}$ (decomp.); ${ }^{1} \mathrm{H}$ NMR (DMSO- $\left.d_{6}, 298 \mathrm{~K}, 500 \mathrm{MHz}\right) \delta_{\mathrm{H}} 7.83$ (s, $1 \mathrm{H},-\underline{\mathrm{NH}}$-, amide), 7.62 (d, $J$ $7.8 \mathrm{~Hz}, 1 \mathrm{H},-\mathrm{NH}-\mathrm{Ac}), 4.99$ (s, OH), 4.86 (brs, 1H, CD-H1), 4.77 (s, OH), 4.60 (s, 1H, GlcNAcH1), 4.53 (s, OH), 3.77 (brs, 2H, GlcNAc-H2, GlcNAc-H3), 3.68 (brs, 2H, GlcNAc-H4, GlcNAc-H6), 3.62 (brs, 1H, GlcNAc-H7), 3.56 (brs, 3H, GlcNAc-H6', CD-H3, CD-H2), 3.47 (brs, 1H, GlcNAc-H7'), 3.39 (brs, 1H, GlcNAc-H8), 3.34 (overlapping with $\mathrm{H}_{2} \mathrm{O}, 1 \mathrm{H}$, GlcNAcH5), 3.47 (brs, 1H, GlcNAc-H8'), 3.02-2.95 (m, 1H, CD-H6), 2.83-2.76 (m, 3H, CD-H6', CDH8), 2.36 (brs, 2H, CD-H7), 1.86 (s, 3H, GlcNAc, $\left.\mathrm{CH}_{3}\right)$ ppm. ${ }^{13} \mathrm{C}$ NMR $\left(\mathrm{D}_{2} \mathrm{O}, 125 \mathrm{MHz}\right) \delta_{\mathrm{C}}$ $173.8(\mathrm{O}=\underline{\mathrm{C}}-\mathrm{Ac}, \mathrm{O}=\underline{\mathrm{C}}-\mathrm{NH}-), 101.4$ (CD-C1), 96.8 (GlcNAc-C1), 83.9 (CD-C4), 72.2 (CD-C2), 71.7 (GlcNAc-C3), 70.9 (GlcNAc-C4), 70.3 (CD-C5, CD-C3), 66.1 (GlcNAc-C7), 60.2 (GlcNAc-C6), 53.2 (GlcNAc-C2), 38.7 (GlcNAc-C8), 35.6 (CD-C7), 32.8 (CD-C6), 28.5 (CDC8), 21.7 (GlcNAc- $\left.\mathrm{CH}_{3}\right)$ ppm. MS (MALDI-TOF) m/z: $3496.50\left([\mathrm{M}+\mathrm{Na}]^{+}\right)$, calcd for $\mathrm{C}_{133} \mathrm{H}_{224} \mathrm{O}_{77} \mathrm{~S}_{7} \mathrm{~N}_{14} \mathrm{Na}$ : 3496.21 . Elemental analysis calcd. for $\mathrm{C}_{133} \mathrm{H}_{224} \mathrm{~N}_{14} \mathrm{O}_{77} \mathrm{~S}_{7} \cdot 0.5 \mathrm{C}_{8} \mathrm{H}_{19} \mathrm{~N}(\%)$ : $\mathrm{C}$ 46.47, H 6.64, N 5.73; found C 46.08, H 7.17, N 5.98.

Octakis\{6-deoxy-6-S-[6-(2-acetamide-2-deoxy- $\alpha$-D-glucopyranose-1'-yl)-4-aza-3-oxohex-1yl]-6-thio\}- $\gamma$-cyclodextrin (6). The title compound was obtained from octakis[6-(oxycarbonylethylthio)-6-deoxy]- $\gamma$-cyclodextrin (2) (100 mg, $0.046 \mathrm{mmol}$ ) and 2'-aminoethyl-2-acetamide-2deoxy- $\alpha$-D-glucopyranose $(165 \mathrm{mg}, 0.624 \mathrm{mmol})$. The same ratio of equivalents of reagents as for 4 were used: HATU (535 mg, $1.407 \mathrm{mmol})$, DMF (22 mL), DIPEA (168 $\mu \mathrm{L}, 0.991 \mathrm{mmol})$. Off-white solid (182 mg 83\%). Mp >175 ${ }^{\circ} \mathrm{C}$ (decomp.); ${ }^{1} \mathrm{H}$ NMR (DMSO- $d_{6}, 298 \mathrm{~K}, 500 \mathrm{MHz}$ ) $\delta_{\mathrm{H}} 7.84(\mathrm{~s}, 1 \mathrm{H},-\underline{\mathrm{NH}}-$, amide), $7.63(\mathrm{~d}, J 6.5 \mathrm{~Hz}, 1 \mathrm{H},-\underline{\mathrm{NH}}-\mathrm{Ac}), 4.99$ (s, OH), 4.90 (brs, 1H, CD$\mathrm{H} 1), 4.78$ (s, OH), 4.66 (s, 1H, GlcNAc-H1), 4.54 (s, OH), 3.68 (s, 1H, GlcNAc-H2), 3.64-3.63 (brs, 2H, GlcNAc-H6, GlcNAc-H7), 3.49-3.45 (brs, 2H, GlcNAc-H6', GlcNAc-H7'), 3.39 (1H, GlcNAc-H8), 3.33 (overlapping with $\mathrm{H}_{2} \mathrm{O}, 1 \mathrm{H}$, GlcNAc-H3), 3.15 (brs, GlcNAc-H7', GlcNAcH8'), 2.98 (m, 1H, CD-H6), 2.77 (brs, 3H, CD-H6', CD-H8), 2.36 (brs, 2H, CD-H7), 1.86 (s, 3H, GlcNAc, $\left.\mathrm{CH}_{3}\right)$ ppm. ${ }^{13} \mathrm{C}$ NMR $\left(\mathrm{D}_{2} \mathrm{O}, 125 \mathrm{MHz}\right) \delta_{\mathrm{C}} 173.8(\mathrm{O}=\underline{\mathrm{C}}-\mathrm{Ac}), 173.6(\mathrm{O}=\underline{\mathrm{C}}-\mathrm{NH}-), 101.4$ (CD-C1), 96.8 (GlcNAc-C1), 83.4 (CD-C4), 72.3 (GlcNAc-C4), 71.7 (CD-C3, CD-C2), 70.8 (GlcNAc-C3), 69.4 (GlcNAc-C7), 66.2 (CD-C5), 60.2 (GlcNAc-C6), 53.1 (GlcNAc-C2), 38.7

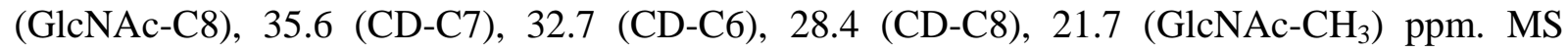
(MALDI-TOF) $m / z$ : $3992.94\left([\mathrm{M}+\mathrm{Na}]^{+}\right)$, calcd for $\mathrm{C}_{152} \mathrm{H}_{256} \mathrm{O}_{88} \mathrm{~S}_{8} \mathrm{~N}_{16} \mathrm{Na}$ : 3992.38. Elemental analysis calcd. for $\mathrm{C}_{152} \mathrm{H}_{256} \mathrm{~N}_{7} \mathrm{O}_{88} \mathrm{~S}_{8} \cdot 2 \mathrm{H}_{2} \mathrm{O}$ (\%): C 45.54, $\mathrm{H} \mathrm{6.53,} \mathrm{N} \mathrm{5.59;} \mathrm{found} \mathrm{C} \mathrm{45.72,} \mathrm{H} \mathrm{6.57,}$ N 5.76 .

Mono\{6-deoxy-6-S-[6-( $\alpha$-D-mannopyranose-1'-yl)-4-aza-3-oxohex-1-yl]-6-thio\}- $\beta$-cyclodextrin (8). The title compound was obtained using mono[6-(oxycarbonylethylthio)-6-deoxy]- $\beta$ - 
cyclodextrin (7) (52 $\mathrm{mg}, 0.0417 \mathrm{mmol})$ and 2'-aminoethyl- $\alpha$-D-mannopyranose (16 mg, 0.071 $\mathrm{mmol})$. The same ratio of equivalents of reagents as described for 9 below were used: HATU (61 mg, $0.159 \mathrm{mmol})$, DMF (9 mL), DIPEA (19 $\mu \mathrm{L}, 0.113 \mathrm{mmol})$. Off-white solid (60 mg, 52\%). $\mathrm{Mp}>225{ }^{\circ} \mathrm{C}$ (decomp.); ${ }^{1} \mathrm{H}$ NMR (DMSO- $\left.d_{6}, 298 \mathrm{~K}, 500 \mathrm{MHz}\right) \delta_{\mathrm{H}} 5.75$ (m, OH), 4.82 (brs, $1 \mathrm{H}$, CD-H1), 4.59 (s, 1H, Man-H1), 4.45 (s, OH), 3.37 (ap.d, 1H, Man-H2), 3.66 (m, 4H, CD-H3, CD-H6-OH, Man-H7), 3.53 (m, 1H, Man-H7'), 3.36 (overlapping with $\mathrm{H}_{2} \mathrm{O}, 6 \mathrm{H}$, Man-H6, CDH4, CD-H2, Man-H8), 3.13 (m, 2H, CD-H6, H6'-SCH $), 3.02$ (m, 2H, CD-H8), 2.34 (m, 2H, CD-H7) ppm. ${ }^{13} \mathrm{C}$ NMR (DMSO- $\left.d_{6}, 125 \mathrm{MHz}\right) \delta_{\mathrm{C}} 170.7$ (O=C-Ac), 169.5 (O=-ㅡ-NH-), 101.7 (CD-C1), 99.5 (Man-C1), 81.0 (CD-C4), 72.4 (CD-C3), 71.8 (CD-C2), 69.8 (Man-C2), 65.2 (Man-C7), 60.8 (Man-C6), 60.2 (CD-C6-OH), 38.3 (CD-C6-SCH ${ }_{2}$ ), 35.2 (CD-C7), 32.9 (CDC8) ppm. MS (ESI) $m / z: 1450.9\left([\mathrm{M}+\mathrm{Na}]^{+}\right)$, calcd for $\mathrm{C}_{53} \mathrm{H}_{89} \mathrm{NO}_{41} \mathrm{SNa}$ : 1450.46. Elemental analysis calcd. for $\mathrm{C}_{53} \mathrm{H}_{89} \mathrm{NO}_{41} \mathrm{~S} .0 .2 \mathrm{C}_{5} \mathrm{H}_{4} \mathrm{~N}_{4} \mathrm{O} \cdot 6 \mathrm{H}_{2} \mathrm{O}(\%)$ : C 41.48, H 6.56, N 1.61; found C 41.21, H 6.55, N 2.02.

Mono\{6-deoxy-6-S-[6-(2-acetamide-2-deoxy- $\alpha$-D-glucopyranose-1'-yl)-4-aza-3-oxohex-1-yl]6-thio\}- $\boldsymbol{\beta}$-cyclodextrin (9). HATU (121 mg, $0.320 \mathrm{mmol}$ ) was added to a stirred solution of mono[6-(oxycarbonylethylthio)-6-deoxy]- $\beta$-cyclodextrin (7) (104 mg, $0.084 \mathrm{mmol}$ ) in DMF (22 $\mathrm{mL})$ at $0{ }^{\circ} \mathrm{C}$. After $1 \mathrm{~h}$ DIPEA $(38 \mu \mathrm{L}, 0.225 \mathrm{mmol})$ and 2'-aminoethyl-2-acetamido-2-deoxy- $\alpha$ D-glucopyranose $(37.5 \mathrm{mg}, 0.142 \mathrm{mmol})$ in DMF $(0.3 \mathrm{~mL})$ were added and the mixture was left to stir for $24 \mathrm{~h}$. The solvent was then evaporated to dryness, the resulting mixture was dissolved in doubly distilled water $(2 \mathrm{~mL})$, the $\mathrm{pH}$ was adjusted to 7 with $1 \mathrm{~N} \mathrm{HCl}$ and the solution was dialysed for $72 \mathrm{~h}$ to remove the low-molecular-weight impurities. Lyophilization afforded an offwhite solid (123 mg, 76\%). Mp >218 ${ }^{\circ} \mathrm{C}$ (decomp.); ${ }^{1} \mathrm{H}$ NMR (DMSO- $\left.d_{6}, 298 \mathrm{~K}, 500 \mathrm{MHz}\right) \delta_{\mathrm{H}}$ 5.78-5.70 (m, OH), 4.82 (brs, 1H, CD-H1), 4.59 (s, 1H, GlcNAc-H1), 4.54 (s, OH), 4.45 (s, OH), 3.65-3.60 (m, 4H, GlcNAc-H2, GlcNAc-H8, CD-타, H6'-OH), 3.56 (brs, 1H, GlcNAc-H7), 3.46 (m, 2H, GlcNAc-H6), 3.33 (overlapping with $\mathrm{H}_{2} \mathrm{O}, 4 \mathrm{H}$, GlcNAc-H7, CD-H4, CD-H2, CD-H3), 3.15-3.11 (m, 1H, GlcNAc-H8'), 3.01 (m, 2H, CD-ㅌ, H6'-SCH $), 2.75$ (m, 2H, CD-H8), 2.35 $(\mathrm{m}, 2 \mathrm{H}, \mathrm{CD}-\mathrm{H} 7), 1.85$ (s, 3H, GlcNAc, $\left.\mathrm{CH}_{3}\right) \mathrm{ppm} .{ }^{13} \mathrm{C}$ NMR (DMSO- $\left.d_{6}, 125 \mathrm{MHz}\right) \delta_{\mathrm{C}} 170.7$ $(\mathrm{O}=\underline{\mathrm{C}}-\mathrm{Ac}), 169.5$ (O=C- $-\mathrm{NH}-), 101.9$ (CD-C1), 97.4 (GlcNAc-C1), 81.5 (CD-C4), 73.0 (CD-C2),

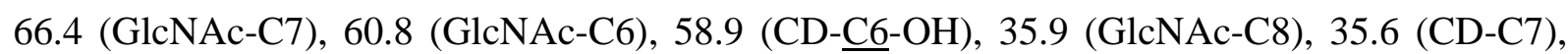
33.3 (CD-C6-SCH ${ }_{2}$ ), 28.5 (CD-C8), 22.7 (GlcNAc-CH ${ }_{3}$ ) ppm. MS (MALDI-TOF) m/z: 1491.7 $\left([\mathrm{M}+\mathrm{Na}]^{+}\right)$, calcd for $\mathrm{C}_{55} \mathrm{H}_{92} \mathrm{~N}_{2} \mathrm{O}_{41} \mathrm{SNa}$ : 1491.49. Elemental analysis calcd. for $\mathrm{C}_{55} \mathrm{H}_{92} \mathrm{~N}_{2} \mathrm{O}_{41} \mathrm{~S} \cdot 8 \mathrm{H}_{2} \mathrm{O}(\%)$ : C 40.94, H 6.74, N 1.73; found C 41.27, H 6.16, N 2.22.

Hydrolysis of ampicillin in the presence of the enzyme $\boldsymbol{\beta}$-lactamase. $\beta$-Lactamase (EC 3.5.2.6) from Enterobacter cloacae $\geq 97 \%$ pure powder was obtained from Sigma-Aldrich. Measurements were carried out in a phosphate buffer solution $\left(\mathrm{Na}_{2} \mathrm{HPO}_{4} / \mathrm{NaH}_{2} \mathrm{PO}_{4}\right)$ in $\mathrm{D}_{2} \mathrm{O}(250$ $\mu \mathrm{L})$ at $\mathrm{pH}$ 7. To a solution of ampicillin $(2.69 \mathrm{mM}, 0.5 \mathrm{mg}$ ampicillin/ $0.5 \mathrm{~mL}$ buffer $)$ a solution of $\beta$-lactamase (Sigma) in $\mathrm{D}_{2} \mathrm{O}(100 \mu \mathrm{L}, 0.5 \mathrm{mg} \beta$-lactamase $/ 1 \mathrm{~mL})$ was added. The mixture was placed in a $5 \mathrm{~mm}$ NMR tube and kept at $25^{\circ} \mathrm{C}$ in a thermostated bath near the NMR instrument. ${ }^{1} \mathrm{H}$ NMR spectra were recorded at various time intervals, and the growth of the methyl peaks at 
$1.15 \mathrm{ppm}$, owing to emergence of hydrolysis products relative to the total phenyl group signal, were monitored with time. The solutions $2, \mathbf{4 , 6}$ and maltoheptaose added were $13.45 \mathrm{mM}$. The points of each curve were normalised. The rate constants $(k)$ were obtained from linear fitting to the equation $\ln \left(\left[\mathrm{A}_{0}\right] /[\mathrm{A}]\right)=k \mathrm{t}$, where $\left[\mathrm{A}_{0}\right]$ is the initial ampicillin concentration and $[\mathrm{A}]$ is the concentration at time $t$.

Binding studies with White Light Reflectance Spectroscopy (WLRS). Protein solutions were prepared: WGA $(0.8 \mu \mathrm{M}$; GNL, $0.2 \mu \mathrm{M})$ in PBS, $\mathrm{pH}$ 7.4. The solutions were left to stand for 12 $\mathrm{h}$ at $4{ }^{\circ} \mathrm{C}$ before deposition on the interferometric WLRS setup, previously described in detail. ${ }^{27,28}$ Briefly, four-inch silicon wafers with a thermally grown $300 \mathrm{~nm}$ thick $\mathrm{SiO}_{2}$ film as the interferometric layer were used, upon which a thin novolac resin film (AZ-5214, AZ-EM materials) was deposited by spin coating and post-baked at a high temperature $\left(180{ }^{\circ} \mathrm{C}, 1 \mathrm{~h}\right)$ to improve coating efficiency (50 to $100 \AA$ ). The coated wafer was placed in the incubation-fluidic cell and the protein solutions were channeled in at $60 \mu \mathrm{L} / \mathrm{min}$ and $\Delta \lambda_{\max }$ was monitored until a plateau was reached. The protein solutions were allowed to stand without flow in the setup for 12 $\mathrm{h}$ at room temperature $\left(21-25{ }^{\circ} \mathrm{C}\right)$. The effective thickness of the formed layer was inferred by fitting the experimental spectrum with the reflectance equation in the region around the extremum (590-680 nm). The films were subsequently washed with PBS with a flow of 60 $\mu \mathrm{L} / \mathrm{min}$ followed by the introduction of each of the compounds dissolved in PBS with the same flow rate at the following concentrations: $\mathbf{5}(10 \mu \mathrm{M}), \mathbf{9}(100 \mu \mathrm{M})$, D-GlcNAc $(1 \mathrm{mM})$ and $\mathbf{3}(100$ $\mu \mathrm{M})$. with WGA; $3(100 \mu \mathrm{M})$ and $8(100 \mu \mathrm{M})$ with GNL.

Supporting information. Reaction schemes and conditions for the monosaccharides with 2'-aminoethyl linkers; 2D spectra and assignments of key compounds showing the connectivity of the monosaccharide appendages to the cyclodextrin core; 2D ROESY NMR of the cavity bound complexes; hydrolysis kinetics; analysis of WLRS results.

\section{Acknowledgements}

Funding by program PENED 2003 (25\% GSRT, 75\% EU) and Pharmathen S.A. is kindly acknowledged. Dr. G. Torri and E. Urso, Istituto di Ricerche Chimiche e Biochimiche "G. Ronzoni" Milano, Italy, are thanked for the MALDI-TOF MS measurements.

\section{References}

1. Lis, H.; Sharon, N. Chem. Rev. 1998, 98, 637. http://dx.doi.org/10.1021/cr940413g

2. Sharon, N. Biochim. Biophys. Acta 2006, 1760, 527. 
3. Sharon, N.; Lis, H.: Lectins, $2^{\text {nd }}$ Ed. Springer:Dordrecht,, 2007.

http://dx.doi.org/10.1007/978-1-4020-6953-6

4. Badjica, J. D., Nelson, A., Cantrill, S. J., Turnbull, W. B., Stoddart, J. F. Acc. Chem. Res. 2005, 38, 723.

http://dx.doi.org/10.1021/ar040223k

5. Mammen, M.; Choi, S.-K.; Whitesides, G. M.: Angew. Chem., Int. Ed. Engl. 1998, 37, 2754. http://dx.doi.org/10.1002/(SICI)1521-3773(19981102)37:20<2754::AIDANIE2754>3.0.CO;2-3

6. Attioui, F.; Al-Omar, A.; Leray, E.; Parrot-Lopez, H.; Finance, C. R. B. Biol. Cell. 1994, 82, 161. http://dx.doi.org/10.1016/S0248-4900(94)80018-9

7. Ortiz Mellet, C.; Benito, J. M.; García Fernández, J. M.; Law, H.; Chmurski, K.; Defaye, J.; O’Sullivan, M. L.; Caro, H. N. Chem. -Eur. J. 1998, 4, 2523. http://dx.doi.org/10.1002/(SICI)1521-3765(19981204)4:12<2523::AIDCHEM2523>3.0.CO;2-2

8. García-López, J. J.; Santoyo-González, F.; Vargas-Berenguel, A.; Giménez-Martínez, J. J. Chem. -Eur. J. 1999, 5, 1775. http://dx.doi.org/10.1002/(SICI)1521-3765(19990604)5:6<1775::AIDCHEM1775>3.0.CO;2-2

9. Baussane, I.; Benito, J. M.; Ortiz Mellet, C.; García Fernández, J. M.; Defaye, J. ChemBiochem. 2001, 10, 777. http://dx.doi.org/10.1002/1439-7633(20011001)2:10<777::AID-CBIC777>3.0.CO;2-C

10. Furuike, T.; Sadamoto, R.; Niikura, K.; Monde, K. N. S.; Nishimura, S. I. Tetrahedron 2005, $61,1737$. http://dx.doi.org/10.1016/j.tet.2004.12.035

11. Carpenter, C.; Nepogodiev, S.A. Eur. J. Org. Chem. 2005, 3286. http://dx.doi.org/10.1002/ejoc.200500146

12. Gómez-García, M.; Benito, J. M.; Butera, A. P.; Ortiz Mellet, C.; García Fernández, J. M.; Jiménez Blanco, J. L. J. Org. Chem. 2012, 77, 7620.

13. Grunstein, D.; Maglinao, M.; Kikkeri, R.; Collot, M.; Barylyuk, K.; Lepenies, B.; Kamena, F.; Zenobi, R.; Seeberger, P. H. J. Am. Chem. Soc. 2011, 33, 13957. http://dx.doi.org/10.1021/ja2036767

14. Vargas-Berenguel, A.; Ortega-Caballero, F.; Casas-Solvas, J. M. Mini-Rev. Org. Chem. 2007, 4,1 . http://dx.doi.org/10.2174/157019307779815901

15. Furuike, T.; Aiba, S.; Nishimura, S. I. Tetrahedron 2000, 56, 9909. http://dx.doi.org/10.1016/S0040-4020(00)00962-5

16. Adam, M. J.; Bennett, D. J.; Bom, A.; Clark, J. K.; Feilden, H.; Hutchinson, E. J.; Palin, R.; Prosser, A.; Rees, D. C.; Rosair, G. M.; Stevenson, D.; Tarver, G. J.; Zhang, M.-Q. J. Med. Chem. 2002, 45, 1806. 
http://dx.doi.org/10.1021/jm011107f

17. Izumi, M.; Okumura, S.; Yuasa, H.; Hashimoto, H. J. Carbohydr. Chem. 2003, 22, 317. http://dx.doi.org/10.1081/CAR-120023475

18. Roy, R.; Kim, J. M. Tetrahedron 2003, 59, 3881. http://dx.doi.org/10.1016/S0040-4020(03)00438-1

19. Disney, M. D.; Seeberger, P. H. Chem. Biol. 2004, 11, 1701. http://dx.doi.org/10.1016/j.chembiol.2004.10.011

20. Vargas-Berenguel, A.; Ortega-Caballero, F.; Santoyo-González, F.; Giménez-Martínez, J. J.; García-Fuentes, L.; Ortiz-Salmerón, E. Chem. -Eur. J. 2002, 8, 812. http://dx.doi.org/10.1002/1521-3765(20020215)8:4<812::AID-CHEM812>3.0.CO;2-P

21. Hoefler, T.; Wenz, G. J. Inclusion Phenom. Mol. Recognit. Chem. 1996, $25,81$. http://dx.doi.org/10.1007/BF01041541

22. Rontoyianni, A.; Mavridis, I. M.; Hadjoudis, E.; Duisenberg, A. J. M. Carbohydr. Res. 1994, $252,19$. http://dx.doi.org/10.1016/0008-6215(94)90003-5

23. Maffeo, D.; Leondiadis, L.; Mavridis, I.; Yannakopoulou, K. Org. Biomol. Chem. 2006, 4, 1297. http://dx.doi.org/10.1039/b517275f

24. Messner, M.; Kurkov, S. V.; Flavià-Piera, R.; Brewster, M. E.; Loftsson, T. Int. J. Pharm. 2011, 408, 235. http://dx.doi.org/10.1016/j.ijpharm.2011.02.008

25. Schwefel, D.; Maierhofer, C.; Beck, J. G.; Seeberger, S.; Diederichs, K.; Moeller, H. M.; Welte, W.; Wittmann, V. J. Am. Chem. Soc. 2010, 132, 8704. http://dx.doi.org/10.1021/ja101646k

26. Hester, G.; Kaku, H.; Goldstein, I. J.; Wright, C. S. Nat. Struct. Biol. 1995, 2, 472. http://dx.doi.org/10.1038/nsb0695-472

27. Zavali, M.; Petrou, P. S.; Kakabakos, S. E.; Kitsara, M.; Raptis, I.; Beltsios, K.; Misiakos, K. Micro Nano Lett. 2006, 1, 94. http://dx.doi.org/10.1038/nsb0695-472

28. Maffeo, D.; Velkov, Z.; Misiakos, K.; Mergia, K.; Paulidou, A.; Zavali, M.; Mavridis, I. M.; Yannakopoulou, K. J. Colloid Interface Sci. 2011, 358, 369. http://dx.doi.org/10.1016/j.jcis.2011.03.024

29. Masaka, R.; Ogata, M. Y. M.; Yano, M.; Hashimoto, C.; Murata, T.; Kawagishi, H.; Usui, T. Bioorg. Med. Chem. 2010, 18, 621. http://dx.doi.org/10.1016/j.bmc.2009.12.006

30. Brady, B.; Lynam, N.; O’Sullivan, T.; Ahern, C.; Darcy, R. Org. Synth. 2000, 77, 220. 